DALIBOR PEŠIĆ, Ph.D.

E-mail: d.pesic@sf.bg.ac.rs

BORIS ANTIĆ, Ph.D.

E-mail: b.antic@sf.bg.ac.rs

University of Belgrade,

Faculty of Transport and Traffic Engineering

Vojvode Stepe 305, 11000 Belgrade, Serbia

DAVOR BRČIĆ, Ph.D.

E-mail: dbrcic@fpz.hr

University of Zagreb,

Faculty of Transport and Traffic Sciences

Vukelićeva 4, 10000 Zagreb, Croatia

JELICA DAVIDOVIĆ, M.Sc. (corresponding author)

E-mail: jelicadavidovic@yahoo.com

University of Belgrade,

Faculty of Transport and Traffic Engineering

Vojvode Stepe 305, 11000 Belgrade, Serbia
Human - Transport Interaction

Review

Submitted: Mar. 30, 2014

Approved: May 27, 2015

\title{
DRIVER'S ATTITUDES ABOUT THE IMPACT OF CAFFEINE AND ENERGY DRINKS ON ROAD TRAFFIC SAFETY
}

\section{ABSTRACT}

Large amounts of energy drinks and caffeine, which is the main ingredient of energy drinks, produce a negative effect on the drivers, and therefore affect traffic safety.

In order to determine the attitudes of drivers toward the impact of energy drinks and caffeine, a research was conducted using a questionnaire form and the targeted group of the survey were drivers. The research was conducted in the City of Belgrade in December 2012. There were 420 survey papers distributed to drivers of different age groups of which 412 were returned. The survey was completely anonymous and consisted of two parts. The first part was related to basic demographic information about the respondents and it had 8 closed type questions. These questions were responded by circling one of the offered answers. The second part of the survey referred to determining the driver's attitudes about energy drinks and caffeine. The second part consisted of 26 questions and respondents were to use a five-level scale in order to show to what extent they agree or disagree with any of the listed statements.

The results show that energy drinks are consumed mostly by young people, less than 25 years old. The effect of caffeine on gender is statistically significant. Headache is the reason why caffeine (25\%) is consumed more than energy drinks (8\%).

Major impact of energy drinks and caffeine on road safety indicates a required activity in this area such as education.

\section{KEY WORDS}

traffic safety; energy drinks; caffeine; the influence on drivers' behaviour;

\section{INTRODUCTION}

Nowadays, fatigue as the cause of traffic accidents attracts a lot of attention around the world. Traffic accidents that occur as result of fatigue have severe consequences, as they usually happen when speeding and the driver often fails to react. The largest number of accidents related to fatigue occurs in the morning, between 04:00 and 06:00. In order to overcome fatigue, drivers avoid driving in the early hours of the morning, but some also use a psychostimulant, most commonly caffeine [1]. Beside caffeine, drivers often consume energy drinks whose effects are several times stronger than those of caffeine [2].

In the last decade an increase in the consumption of energy drinks and caffeine was recorded, especially among teenagers and young students. Energy drinks contain caffeine, taurine, glucuronolactone, B vitamins, and Inositol. Larger doses (100-300 mg) of caffeine show improvement of driving performance [3-4].

Some studies show positive effects of small doses of caffeine, which gives positive effects on the time of reaction, performance and mood [5-6]. Studies showed that taurine as an integral part of energy drinks, visually reduces fatigue [7]. The influence of taurine on the central nervous system is not clear [8]. The influence of B vitamins on driving is also unknown. Neither is known the impact of glucuronolactone [9]. Glucose produces a positive impact of both beverages because it contains sugar. Their combination has a 
positive effect on observation, attention and driving performance. In the laboratory tests, mental abilities, such as the time of reaction, arousal, subjective alertness, concentration and memory [10], as well as the driver capability in a stressful situation are improved [11]. In all previous studies where energy drinks were consumed there was an improvement in driving [12]. Some of energy drinks, such as Red-Bull, improve driving performance significantly and reduce sleepiness of drivers during long drives on the highway [13].

Caffeine has a significant effect on sleeping. Caffeine acts as an agent that facilitates the production of resources required to sustain a consistently high level of signal detection over time [14]. Truck drivers ingest the equivalent amount of caffeine as if they drank 3.3 cups or 6.6 cups of coffee in a row, which signifies a large amount of caffeine. This leads the drivers to lose their concentration and attention ability, and increases the probability of accidents [15]. Moreover, there is caffeine in drinks that can produce energy very quickly, such as energy drinks. The caffeine in combination with taking a "nap" is not favourable in the early morning hours, especially for drivers who did not sleep the previous night, because they might fall into a deep

Table 1 - Review of literature

\begin{tabular}{|c|c|c|c|}
\hline Authors & Target & Method & Finding \\
\hline $\begin{array}{l}\text { Monique, } \\
2010\end{array}$ & $\begin{array}{l}\text { To examine if } \\
\text { Red Bull® En- } \\
\text { ergy Drink can } \\
\text { counteract sleepi- } \\
\text { ness and driving } \\
\text { impairment during } \\
\text { prolonged driving. }\end{array}$ & $\begin{array}{l}\text { Twenty-four healthy volunteers participated in } \\
\text { this double-blind placebo-controlled crossover } \\
\text { study. After } 2 \text { h of highway driving in the STISIM } \\
\text { driving simulator, subjects had a 15-min break } \\
\text { and consumed Red Bull } ® \text { Energy Drink ( } 250 \mathrm{ml} \text { ) } \\
\text { or placebo (Red Bull } \circledast \text { Energy Drink without the } \\
\text { functional ingredients: caffeine, taurine, glucuro- } \\
\text { nolactone, B vitamins (niacin, pantothenic acid, } \\
\text { B6, B12), and inositol) before driving for two ad- } \\
\text { ditional hours. A third condition comprised } 4 \mathrm{~h} \text { of } \\
\text { uninterrupted driving. Primary parameter was the } \\
\text { standard deviation of lateral position (SDLP), i.e., } \\
\text { the weaving of the car. Secondary parameters } \\
\text { included SD speed, subjective driving quality, } \\
\text { sleepiness, and mental effort to perform the test. }\end{array}$ & $\begin{array}{l}\text { Red Bull@ Energy Drink } \\
\text { significantly improves } \\
\text { driving performance and re- } \\
\text { duces driver sleepiness during } \\
\text { prolonged highway driving. }\end{array}$ \\
\hline $\begin{array}{l}\text { Biggs et } \\
\text { al., } 2007\end{array}$ & $\begin{array}{l}\text { To determine } \\
\text { whether caffeine, a } \\
\text { common counter- } \\
\text { measure to driver } \\
\text { sleepiness, affected } \\
\text { a sleepy driver's } \\
\text { ability to monitor } \\
\text { their simulated driv- } \\
\text { ing performance. }\end{array}$ & $\begin{array}{l}\text { Twelve healthy young adults (six males, six females) } \\
\text { participated in three counterbalanced, blinded, } \\
\text { daytime conditions: control [ } 9 \mathrm{~h} \text { time in bed (TIB)], } \\
100 \mathrm{mg} \text { caffeine ( } 4 \mathrm{~h} \text { TIB), and placebo ( } 4 \mathrm{~h} \text { TIB). } \\
\text { Driving performance was measured through lane } \\
\text { drift on a series of 30-min simulated driving ses- } \\
\text { sions. Subjective sleepiness and perception of driv- } \\
\text { ing performance were measured at 5-min intervals } \\
\text { during driving sessions via the Karolinska Sleepi- } \\
\text { ness Scale and a corresponding perception scale. }\end{array}$ & $\begin{array}{l}\text { Strong correlation between sub- } \\
\text { jective measures supports the } \\
\text { postulation that sleepiness is } \\
\text { used as a cue for performance } \\
\text { prediction when sleep restrict- } \\
\text { ed. The relationship between } \\
\text { perceived and actual perfor- } \\
\text { mance after fatigue counter- } \\
\text { measures remains inconclusive. }\end{array}$ \\
\hline $\begin{array}{l}\text { Yildirim, } \\
2003\end{array}$ & $\begin{array}{l}\text { To evaluate the use } \\
\text { of Gripin by long- } \\
\text { distance drivers and } \\
\text { its adverse effects. }\end{array}$ & $\begin{array}{l}\text { A questionnaire was distributed to } 500 \text { truck driv- } \\
\text { ers who volunteered to take part in the study. } \\
\text { They answered the questionnaire face to } \\
\text { face. The questionnaire comprised } 20 \text { ques- } \\
\text { tions about drivers and the subject. }\end{array}$ & $\begin{array}{l}\text { Long-distance drivers use } \\
\text { substances containing caf- } \\
\text { feine in order to prevent } \\
\text { sleep and headache. }\end{array}$ \\
\hline $\begin{array}{l}\text { Horne } \\
\text { and } \\
\text { Reyner, } \\
2002\end{array}$ & $\begin{array}{l}\text { To investigate the } \\
\text { effectiveness of a } \\
\text { well-known FED in } \\
\text { reducing sleepi- } \\
\text { ness in drivers. }\end{array}$ & $\begin{array}{l}\text { Twelve healthy young adults drove an instrumented } \\
\text { car simulator between 14:00 and 17:00 h. Their } \\
\text { sleepiness was enhanced by sleep restriction to } \\
5 \mathrm{~h} \text { the night before. Following a pretreatment } \\
\text { 30-min drive and at the beginning of a 30-min } \\
\text { break, participants were given double-blind } \\
250-\mathrm{ml} \text { FED (containing sucrose, glucose, 80-mg } \\
\text { caffeine, taurine, glucuronolactone and vitamins) } \\
\text { vs. a control drink with the same volume and } \\
\text { the same taste but without caffeine, taurine and } \\
\text { glucuronolactone. Two hours of continuous driving } \\
\text { ensued. Lane drifting, subjective sleepiness } \\
\text { and the electroencephalogram (EEG) } \\
\text { were monitored throughout. }\end{array}$ & $\begin{array}{l}\text { Compared with the control, } \\
\text { the FED significantly reduced } \\
\text { sleep-related driving incidents } \\
\text { and subjective sleepiness for } \\
\text { the first } 90 \text { min of the drive. } \\
\text { There was a trend for the EEG } \\
\text { to reflect less sleepiness during } \\
\text { this period. It was concluded } \\
\text { that the FED is beneficial in } \\
\text { reducing sleepiness and sleep- } \\
\text { related driving incidents under } \\
\text { conditions of afternoon mo- } \\
\text { notonous driving following sleep } \\
\text { restriction the night before. }\end{array}$ \\
\hline
\end{tabular}


sleep, instead of a 15-minute snooze [1]. As in longduration vigils, performance on the abbreviated vigil can be enhanced by caffeine; however, as is the case with long-duration tasks, caffeine does not reduce task-induced stress, suggesting that independent mechanisms subserve signal detection and the emotional sequelae of performing demanding vigilance tasks [14]. Yildirim [15] suggests that energy drinks

Table 1 - Review of literature (continued)

\begin{tabular}{|c|c|c|c|}
\hline Authors & Target & Method & Finding \\
\hline $\begin{array}{l}\text { Horne } \\
\text { and } \\
\text { Reyner, } \\
2000\end{array}$ & $\begin{array}{l}\text { To evaluate caf- } \\
\text { feine as a coun- } \\
\text { termeasure to } \\
\text { driver sleepiness. }\end{array}$ & $\begin{array}{l}\text { In two independent studies following a night of } \\
\text { either restricted or nil sleep, young experienced } \\
\text { drivers drove for } 2 \mathrm{hr}(06: 00-08: 00) \text { continuously } \\
\text { in an immobile car on an interactive, computer- } \\
\text { generated, dull, and monotonous roadway. This } \\
\text { exercise followed ingestion (at 05:30) of } 200 \mathrm{mg} \\
\text { caffeine (=2-3 cups of coffee) versus placebo, } \\
\text { counterbalanced, double blind. Driving incidents } \\
\text { (lane drifting), subjective sleepiness, and } 4-11 \mathrm{~Hz} \\
\text { electroencephalogram (EEG) activity were logged. }\end{array}$ & $\begin{array}{l}\text { In Study } 1 \text { (sleeping 00:00- } \\
\text { 05:00h), caffeine significantly } \\
\text { reduced incidents and subjec- } \\
\text { tive sleepiness throughout the } \\
\text { 2-hr drive, and EEG power for } \\
\text { the second 30-min period. In } \\
\text { Study } 2 \text { (no sleep), sleepiness } \\
\text { affected all measures profound- } \\
\text { ly, and driving was terminated } \\
\text { after } 1 \text { hr. Nevertheless, caf- } \\
\text { feine reduced incidents signifi- } \\
\text { cantly for the first } 30 \text { min and } \\
\text { subjective sleepiness for the } \\
\text { hour. This caffeine dose, feasi- } \\
\text { bly taken via coffee, effectively } \\
\text { reduces early morning driver } \\
\text { sleepiness for about } 30 \text { min fol- } \\
\text { lowing nil sleep, and for around } \\
2 \text { hr after sleep restriction. }\end{array}$ \\
\hline $\begin{array}{l}\text { Regina et } \\
\text { al., } 1974\end{array}$ & $\begin{array}{l}\text { To evaluate caffeine } \\
\text { as a countermea- } \\
\text { sure of alertness }\end{array}$ & $\begin{array}{l}30 \text { min after ingesting } 200 \mathrm{mg} \text { of caffeine or a } \\
\text { placebo, each of } 24,21-26 \mathrm{yr} \text { old males drove } \\
\text { an automobile simulator for } 90 \text { min. Immedi- } \\
\text { ately thereafter, the S ingested a supplemen- } \\
\text { tal dose of } 200 \mathrm{mg} \text { of the medication taken } \\
\text { initially and then drove for another } 90 \text { min. }\end{array}$ & $\begin{array}{l}\text { Both the initial and the } \\
\text { supplemental doses of caf- } \\
\text { feine significantly enhanced } \\
\text { performance beyond that } \\
\text { found with placebo, on each } \\
\text { of } 4 \text { measures of alertness. }\end{array}$ \\
\hline $\begin{array}{l}\text { Childs } \\
\text { and Wit, } \\
2006\end{array}$ & $\begin{array}{l}\text { To investigate } \\
\text { the physiological, } \\
\text { subjective, and } \\
\text { behavioral effects of } \\
0,50,150 \text {, and } 450 \\
\text { mg caffeine in } 102 \\
\text { light, non-dependent } \\
\text { caffeine users. }\end{array}$ & $\begin{array}{l}\text { Using a within-subjects design, subjects participat- } \\
\text { ed in four experimental sessions, in which they re- } \\
\text { ceived each of the four drug conditions in random } \\
\text { order under double-blind conditions. Participants } \\
\text { completed subjective effects questionnaires and } \\
\text { vital signs were measured before and at repeated } \\
\text { time points after drug administration. Forty min- } \\
\text { utes after the capsules were ingested, subjects } \\
\text { completed behavioral tasks that included tests of } \\
\text { sustained attention, short-term memory, psycho- } \\
\text { motor performance, and behavioral inhibition. }\end{array}$ & $\begin{array}{l}\text { Acute doses of caffeine, at } \\
\text { levels typically found in a cup } \\
\text { of coffee, produce stimulant- } \\
\text { like subjective effects and } \\
\text { enhance performance in light, } \\
\text { non-dependent caffeine us- } \\
\text { ers. These findings support } \\
\text { the idea that the drug has } \\
\text { psychoactive effects even in } \\
\text { the absence of withdrawal. }\end{array}$ \\
\hline $\begin{array}{l}\text { Haskell } \\
\text { et al., } \\
2005\end{array}$ & $\begin{array}{l}\text { To investigate the } \\
\text { acute cognitive } \\
\text { and mood ef- } \\
\text { fects of caffeine } \\
\text { in habitual users } \\
\text { and habitual non- } \\
\text { users of caffeine. }\end{array}$ & $\begin{array}{l}\text { Following overnight caffeine withdrawal, } 24 \\
\text { habitual caffeine consumers (mean= } 217 \mathrm{mg} / \\
\text { day) and } 24 \text { habitual non-consumers ( } 20 \mathrm{mg} / \\
\text { day) received a } 150 \mathrm{ml} \text { drink containing either } \\
75 \text { or } 150 \mathrm{mg} \text { of caffeine or a matching placebo, } \\
\text { at intervals of }>\text { or }=48 \mathrm{~h} \text {. Cognitive and mood } \\
\text { assessments were undertaken at baseline and } \\
30 \text { min post-drink. These included the Cognitive } \\
\text { Drug Research computerised test battery, two } \\
\text { serial subtraction tasks, a sentence verification } \\
\text { task and subjective visual analogue mood scales. }\end{array}$ & $\begin{array}{l}\text { These results do not support a } \\
\text { withdrawal alleviation model. } \\
\text { Differences in the patterns of re- } \\
\text { sponses to caffeine by habitual } \\
\text { consumers and habitual non- } \\
\text { consumers may go some way to } \\
\text { explaining why some individuals } \\
\text { become caffeine consumers. }\end{array}$ \\
\hline $\begin{array}{l}\text { Zhang et } \\
\text { al., } 2004\end{array}$ & $\begin{array}{l}\text { To evaluate the } \\
\text { effects of dietary } \\
\text { taurine supplemen- } \\
\text { tation on visual } \\
\text { fatigue induced } \\
\text { by visual display } \\
\text { terminals (VDT) work }\end{array}$ & $\begin{array}{l}25 \text { male college students aged from } 20 \text { to } \\
24 \text { years who were not engaged in VDT work } \\
\text { were selected to participate in the study. Vol- } \\
\text { unteers were randomly assigned to either the } \\
\text { taurine supplementation }(n=13) \text { or the pla- } \\
\text { cebo supplementation control group }(n=12) \text {. }\end{array}$ & $\begin{array}{l}\text { The results suggest that taurine } \\
\text { supplementation alleviates visu- } \\
\text { al fatigue induced by VDT work. }\end{array}$ \\
\hline
\end{tabular}


can be slightly more effective at mild sleepiness than caffeine under the same conditions. Consuming energy drinks that contain $80 \mathrm{mg}$ of caffeine and other ingredients such as taurine, is much more effective than coffee with the same amount of caffeine [12]. Some psychotropic drugs containing caffeine are known to play an important role in road traffic accidents as they cause sleepiness and stumbling after a certain period. In view of this fact, drivers should be made aware of the dangers of driving for long periods, and the use of caffeine containing substances which can cause dependency must be prevented [15].

This paper confirms previous research findings that caffeine and energy drinks (containing also caffeine) are good counter-measures to eliminate sleepiness. In contrast to previous studies which used simulators, or interviewed professional drivers, we have shown driver's attitudes about the impact of caffeine and energy drinks on their driving in one city.

The aim of this study is to determine the attitudes of drivers toward the impact of energy drinks and caffeine, and to give a basis for further research, considering that in this area no similar studies have been conducted up to now.

In addition to the introduction giving a review of previous research, the second chapter presents the basic hypotheses and methodology, also the way and methods of the research. The third chapter presents the results of research. The fourth chapter is a discussion of the results. At the end of the paper is the conclusion of the proposed measures and the future course of action.

Table 1 - Review of literature (continued)

\begin{tabular}{|c|c|c|c|}
\hline Authors & Target & Method & Finding \\
\hline $\begin{array}{l}\text { Kim, } \\
2003\end{array}$ & $\begin{array}{l}\text { It is hypothesized } \\
\text { that the combinato- } \\
\text { rial influences of } \\
\text { these ingredients } \\
\text { are responsible for } \\
\text { Red Bull's proposed } \\
\text { effects }(9,10) \text {. }\end{array}$ & Critical reviews of hypothesis. & $\begin{array}{l}\text { Concludes that caffeine } \\
\text { alone may be responsible } \\
\text { for the proposed effects. }\end{array}$ \\
\hline $\begin{array}{l}\text { Warbur- } \\
\text { ton et al., } \\
2001\end{array}$ & $\begin{array}{l}\text { To test participants } \\
\text { who had minimal } \\
\text { deprivation from } \\
\text { caffeine (an hour } \\
\text { or less) with an } \\
80-\mathrm{mg} \text { caffeinated } \\
\text { (80 mg/250 ml), } \\
\text { taurine-containing } \\
\text { beverage (com- } \\
\text { mercially available) } \\
\text { verum, which also } \\
\text { contained sugars, } \\
\text { glucuronolactone } \\
\text { and vitamins. The } \\
\text { placebos in the two } \\
\text { studies were a sug- } \\
\text { ar-free and a sugar- } \\
\text { containing drink, in } \\
\text { order to examine the } \\
\text { effects of sugar. }\end{array}$ & $\begin{array}{l}\text { In total, } 42 \text { participants were tested with a } \\
\text { rapid visual information test, a verbal reason- } \\
\text { ing test, a verbal and non-verbal memory test } \\
\text { and a set of mood measures. Prior to testing, } \\
\text { they were allowed ad libitum caffeinated bever- } \\
\text { ages until } 1 \mathrm{~h} \text { before testing (study } 1 \text { ) and unre- } \\
\text { stricted caffeine use before testing (study } 2 \text { ). }\end{array}$ & $\begin{array}{l}\text { Moderate doses of caffeine } \\
\text { and taurine can improve } \\
\text { information processing in } \\
\text { individuals who could not have } \\
\text { been in caffeine withdrawal. }\end{array}$ \\
\hline $\begin{array}{l}\text { Seidl et } \\
\text { al., } 2000\end{array}$ & $\begin{array}{l}\text { Caffeine - and } \\
\text { taurine-containing } \\
\text { drinks have been } \\
\text { on the European } \\
\text { market for about } \\
\text { a decade, and } \\
\text { research on the indi- } \\
\text { vidual constituents } \\
\text { of these drinks in- } \\
\text { dicates an improve- } \\
\text { ment in cognitive } \\
\text { performance result- } \\
\text { ing from consump- } \\
\text { tion of such drinks }\end{array}$ & $\begin{array}{l}\text { In this double-blind, placebo-controlled study } \\
\text { using } 10 \text { graduate students, we obtained the } \\
\text { P300 components of event-related potential } \\
\text { (ERP) waveforms following an auditory oddball } \\
\text { paradigm, measured motor reaction time, and } \\
\text { applied the d2 test for the assessment of atten- } \\
\text { tion. Status of mood was assessed by the "Basler- } \\
\text { Befindlichkeitsbogen" questionnaire, a standard } \\
\text { test for evaluation of feelings of wellbeing. }\end{array}$ & $\begin{array}{l}\text { The findings clearly indicate that } \\
\text { the mixture of three key ingre- } \\
\text { dients of Red Bull Energy Drink } \\
\text { used in the study (caffeine, } \\
\text { taurine, glucuronolactone) have } \\
\text { positive effects upon human } \\
\text { mental performance and mood. }\end{array}$ \\
\hline
\end{tabular}




\section{BASIC HYPOTHESIS AND RESEARCH METHODOLOGY}

In order to determine the impact and the attitudes of drivers about energy drinks and caffeine, this research was conducted using a questionnaire. The survey was completely anonymous and consisted of two parts. First, a survey is made to collect data about impressions/sensations related to consumption of caffeine and energy drinks related to driving security. Second, such data were analyzed by applying a set of statistical tests in order to determine which factors influence the different answers.

The first part was related to basic demographic information about the respondents and it had 8 questions, responded by circling one of the offered answers.

All questions were closed type questions, and the respondents in the first part responded by circling one of the offered answers. In the second part the respondents were to use the five-level scale in order to show to what extent they agree or disagree with any of the listed statements (1 - "I completely disagree"; 2 - "I disagree"; 3 - "neither agree nor disagree"; 4 - "I agree"; 5 - "I completely agree".

The first part of the survey consists of questions to collect the basic data on the respondents (gender, age, education level), and the length and duration of driving (average weekly mileage, how often they drive more than 30 minutes at a time). Then, issues related to the frequency of consumption (How often do you consume energy drinks? How often do you consume coffee, tea? How much caffeine do you intake in your organism, except through coffee and tea?).

The second part of the survey referred to determining driver's attitudes about energy drinks and caffeine and consisted of 26 questions (13 about energy drinks and 13 about caffeine).

The survey contained repeated questions concerning both energy drinks and caffeine in order to determine the reliability of the questionnaire.

The research was conducted in the City of Belgrade in December 2012. The survey was distributed randomly. Just during the analysis of the results these were divided according to gender, age and education. There were 420 survey papers distributed to drivers of different age groups of which 412 were returned.

The basic hypothesis is that energy drinks and caffeine have a negative impact on driving. During the research the survey method in combination with a statistical method was used. In order to compare the driver's attitudes toward gender, age and level of education, as well as with the results of other similar studies methods of analysis and comparison were used.

The database of the responses was formed and the data were analysed using SPSS Statistics, version 20.0. Normality of distribution was tested by inspection of histograms and Kolmogorov-Smirnov test. Since the distribution of all the measured variables significantly deviated from the normal distribution, non-parametric tests were used. Median (Md), absolute (n) and relative $(\% n)$ frequencies were used for the description, and Pearson's $\mathrm{x} 2$ test, Kruskal-Wallis's $\mathrm{H}$ test and Mann-Whitney's $U$ test were used to evaluate the significance of differences.

The limit of statistical significance $(\alpha)$ was set at $5 \%$. If $\mathrm{p} \leq 0.05, \mathrm{H}_{0}$ is rejected and $\mathrm{H}_{\mathrm{a}}$ accepted, and if $p>0.05 \mathrm{H}_{0}$ is accepted. When the Sig. value is 0.05 or less, the probability that the difference between the Observed $\mathrm{N}$ and Expected $\mathrm{N}$ value was due to chance is $5 \%$ or less.

The null hypothesis for Pearson's $x 2$ test was set $\left(\mathrm{H}_{0}\right)$ as follows: there is no statistically significant difference between variables, and also the working hypothesis $\left(\mathrm{H}_{\mathrm{a}}\right)$ as follows: There is a statistically significant difference between variables.

The null hypothesis for Man Whitney and KruskalWallis test was set $\left(\mathrm{H}_{0}\right)$ as follows: there is no statistically significant difference between treatments and also the working hypothesis $\left(\mathrm{H}_{\mathrm{a}}\right)$ as follows: there is a statistically significant difference between treatments.

There were 412 drivers participating in the research, $48.1 \%$ females and $51.9 \%$ males. Most of the respondents were in the age group of 18-25 years, $68.9 \%$, then $11.2 \%$ of those aged between 36 and 45 years, $8.3 \%$ that belong to the age group $26-35,5.8 \%$ belonging to the age group $46-55,3.9 \%$ were those who belong to the age group of $56-65$, and $1.9 \%$ of the respondents were older than 65 years. Among the respondents $56.3 \%$ had secondary school education, $31.1 \%$ tertiary education, whereas $7.3 \%$ had elementary education.

The results show that in $64 \%$ of cases the respondents drive less than $100 \mathrm{~km}$ a week, whereas 4.4\% travel more than $400 \mathrm{~km}$ in an average week. Ten percent of respondents drive more than 30 minutes at a time every day, whereas $30 \%$ do so rarely.

\section{RESULTS}

The results show that in $64 \%$ of cases the respondents drive less than $100 \mathrm{~km}$ a week, whereas 4.4\% travel more than $400 \mathrm{~km}$ in an average week. Ten percent of respondents drive more than 30 minutes at a time every day, whereas $30 \%$ do so rarely.

In the second part of the survey two questions were repeated, one concerning the attitude to energy drinks and the other one concerning caffeine. It was done in order to determine and verify the reliability of the survey. The Cronbach's Alpha reliability Coefficient of the questions that deals with the energy drinks was 0.74 and that dealing with caffeine was 0.8 . 


\subsection{Frequency of consuming energy drinks and coffee, tea}

The study found that more than half of the respondents never consume energy drinks (53\%), whereas $34 \%$ consume these only once a month, the remaining $13 \%$ consume more often, $1 \%$ of them consume them several times a day.

When we compare the questions: "How often do you consume energy drinks?" and "How often do you consume coffee, tea?", we get the data that show the percentage of respondents who never consume either energy drinks or coffee and tea (about 9\% of the total sample). The daily intake of caffeine (through coffee and tea) in case of $42 \%$ of the respondents is $1-2$ cups, $19 \%$ consume $3-4$ cups per day and $2 \%$ consume more than five cups a day (Figure 1). The previous studies have indicated that this dose of caffeine affects concentration and driving behaviour, and thus the occurrence of traffic accidents. We know that, on the average, $9 \mathrm{mg}$ of caffeine is found in one cup of coffee $(200 \mathrm{ml})$ and $30 \mathrm{mg}$ of caffeine in one pill of Gripin (tablets containing $30 \mathrm{mg}$ of caffeine and 500 $\mathrm{mg}$ of paracetamol). According to these amounts, if a person took a pill of Gripin, it would be as if they drank 3.3 cups of coffee. When these data are compared to the daily doses in the study done by Yildirim [15] where $72.3 \%$ of the drivers took $1-2$ tablets per day, 20\% took 3-4 and 7.7\% more than 5 tablets a day, it can be noticed that the respondents in this study consumed much less caffeine.
When making this comparison, one should have in mind that in Turkey professional drivers were surveyed, and they drive quite more than those in this study.

\subsection{Gender differences}

The results show that there is only a slight difference in energy drink consumption between the genders, so that there is no statistically significant difference between females and males in the frequency of energy drinks consumption ( $x 2=2.538, p=0.638$ ). As for the frequency of the consumption of coffee and/ or tea, it can be seen that $12 \%$ never consume these beverages, whereas most of the respondents consume 1-2 cups a day, which is considered a moderate amount. Even in this case, there was no significant difference between male and female gender $(x 2=4.095$, $p=0.536)$.

About $75 \%$ of respondents do not consume energy drinks as a replacement for resting. Out of $8 \%$ of the respondents who consume energy drinks so that they need no rest, 3\% are women and 5\% are men.

A statistical significance of the difference in the statements that energy drinks affect their driving was determined for women ( $\mathrm{Md}=3, \mathrm{n}=198$ ) and men (Md $=2, n=214), U=4,503, z=-1.94, p=0.05, r=0.13$. The results of the research whether energy drinks have a positive effect on driving for women and men were compared using $U$-test. There is a statistically significant difference for women ( $M d=3, n=198$ ) and men $(M d=3, n=214), U=4,435, z=-2.08, p=0.04$, $r=0.14$, more men than women (15.1\% vs. $8.4 \%$ ) sup-

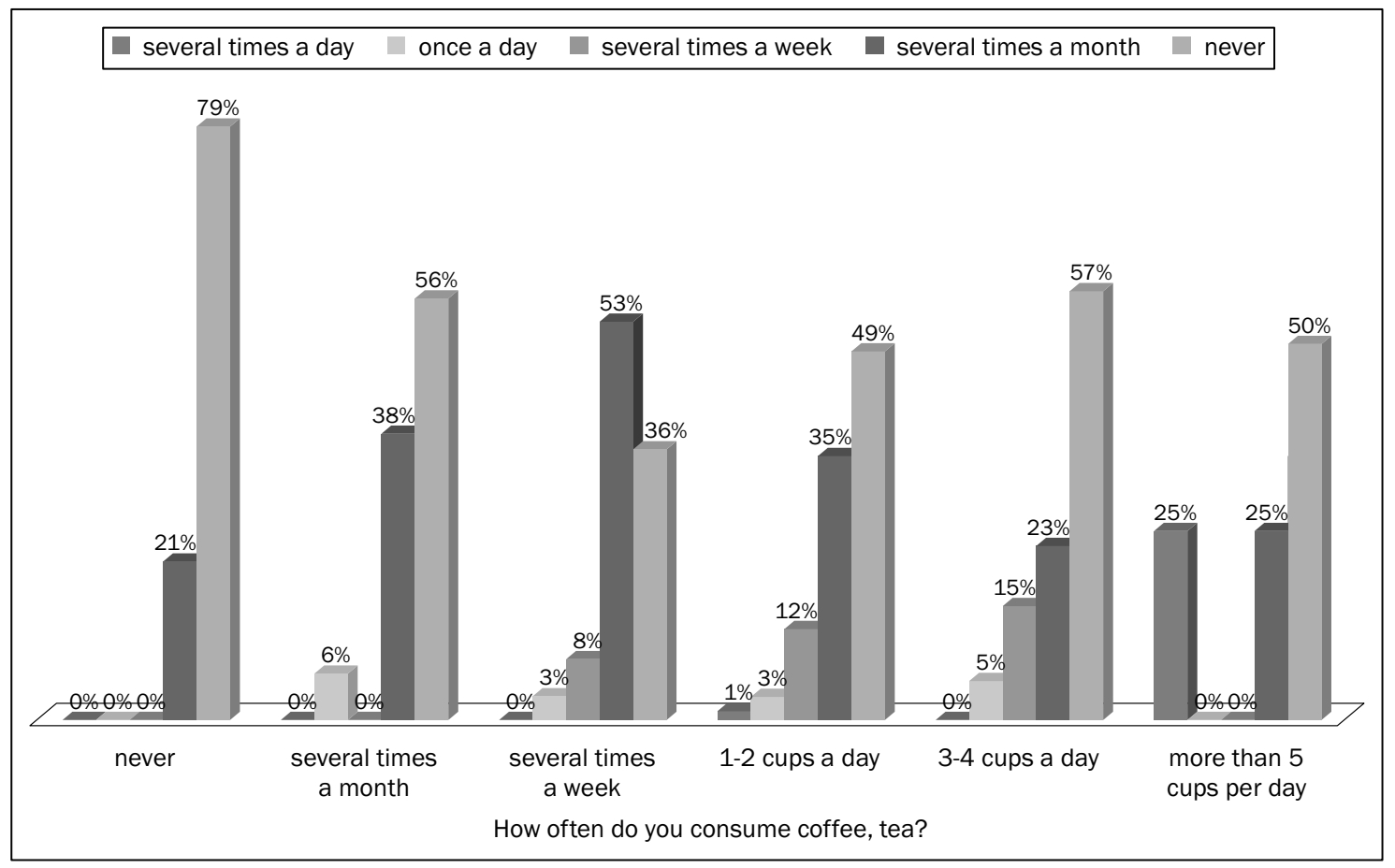

Figure 1 - The frequency of consumption of energy drinks and coffee and tea 
port the view that energy drinks have a positive impact on their driving.

The respondents disagreed with the statement that for them caffeine is a replacement for sleep, $41 \%$ disagreed completely, 32\% disagreed, $11 \%$ were abstained. Only $16 \%$ use caffeine as a substitute for sleep and there are no statistically significant differences between women and men.

In the following results, there are more men than women who believe that caffeine makes them feel more relaxed, but energy drinks do not. A quarter of the respondents agree that caffeine makes them calmer, but only $3.5 \%$ of them agree that after consuming energy drinks they also feel calmer. The caffeine calms more women than men, but most of them believe that energy drinks do not affect them in the same way. Very few respondents believe that caffeine (10\%) and energy drinks (10\%) affect their body causing anxiety. Most respondents feel more rested after taking caffeine, $14 \%$ of women and $15.5 \%$ men.

Very few respondents reported that they felt calmer after consuming energy drinks. The results show that there are more women who consume caffeine, and more men who consume both caffeine and energy drinks when they are sleepy and need to drive. Due to headache, more respondents consume caffeine (about 24\%) than energy drinks (about 8\%). However, when it comes to preventing sleep, the research revealed that energy drinks and caffeine are consumed equally, but women consume more caffeine, and men consume more energy drinks. About $9 \%$ of the respondents believe that in short-terms caffeine reduces fatigue when driving, but energy drinks do not. Also, $9 \%$ of respondents believe that energy drinks briefly relieve fatigue when driving, but the caffeine does not. About $18 \%$ of respondents believe that both caffeine and energy drinks briefly relieve fatigue when driving.

Statistical analysis of driver's attitudes to the impact of energy drinks and caffeine on driving according to gender was performed using the Mann-Withney test. Table 2 shows the results. It should be noted that we determined statistically significant difference between gender and driver attitude "Energy drinks make me feel rested" ( $U=4,465.5, Z=-2.020, p=0.043)$. Men are less prone to support this view. When looking at the distribution by gender statistically significant correlation with the attitude "I do not notice the impact of energy drinks on my driving" was shown.

Drivers attitudes of the impact of caffeine on driving showed no significant differences between women and men.

\subsection{Education level differences}

We found a statistically significant difference between the participant's level of education and fre- quency of consumption of caffeine $(x 2=23.098, p$ $=0.027$ ). Caffeine is least frequently consumed by people with secondary education (37\% never, 33.7\% rarely, 29.3 daily). Pearson's $x 2$ test does not indicate significant difference between the participant's level of education and frequency of consumption of energy drinks $(x 2=12.226, p=0.428)$, nor coffee/tea $(x 2=$ 14.773, $p=0.468)$.

A statistical significance difference was determined in the level of education for the statements that energy drinks make them feel calmer $(x 2=8.657, p=0.034)$ and that energy drinks make them feel nervous ( $x 2=$ $8.826, p=0.032$ ). It was found that significantly more respondents with university education feel calmer, and more nervous.

Participants with higher education consume energy drinks significantly more when they are sleepy and need to drive ( $x 2=9.307, p=0.025)$.

A statistical significance of the difference in the statements "I do not notice the effects of energy drinks on my driving" was determined for the level of education ( $x 2=9.254, p=0.026)$. Respondents with primary education least agree with this statement. Similar results are determined in the attitude "I do not notice the effects of caffeine on my driving" between level of education ( $x 2=8.412, p=0.038$ ).

Kruskal-Wallis's $\mathrm{H}$ test showed a statistical significance difference between level of education ( $\mathrm{X} 2$ $=12.850, p=0.005$ ) for the attitude: "Energy drinks make me feel more relaxed". The most who agree are those with higher education (26.5\%), while most disapproving participants are with primary education (6.6\%).

Kruskal-Wallis's $\mathrm{H}$ test showed significant differences between level of education ( $x 2=9.099, p=$ $0.028)$. Most respondents have secondary education $(56.3 \%)$, followed by post-secondary education (31.1\%). The survey covered $7.3 \%$ with primary and $5.3 \%$ with higher education.

Statistical analysis of driver's attitudes of the impact of energy drinks and caffeine on driving according to education level was performed using the KruskalWallis test (Table 2).

The results showed a statistically significant difference between the level of education and attitude "My concentration is better after consuming energy drinks“ ( $x 2=9.099, p=0.028)$. This attitude was least supported by respondents with primary education (66\% completely disagree), and most by respondents with higher education (23\% agree).

There was also a statistically significant difference between the level of education and attitude "I feel more rested after taking caffeine" ( $x 2=8.412$, $p=0.038)$. Least agree the respondents with secondary education (15.5\%), and most the respondents with higher education (40.6\%). 


\subsection{Age differences}

Kruskal-Wallis's $\mathrm{H}$ test showed a statistical significance of the difference in the frequency of consumption of energy drinks ( $x 2=27.77, p=0.000)$, coffee/ tea $(x 2=35.24, p=0.000)$, caffeine - except coffee/ tea $(x 2=11.686, p=0.039)$ between 6 age groups. $82 \%$ of participants who consume energy drinks several times a week are young drivers (18-25), while participants who are over 56 never consume energy drinks. Coffee/tea is most often consumed by drivers 36-45 years old (more than 3 cups per day); whereas participants who are over 56 never consume energy drinks. One third of respondents over 46 years daily intake caffeine in some other way, unlike other age groups.

Kruskal-Wallis's H test showed a statistical significance difference between age groups $(x 2=13.072, p$ $=0.023$ ) for the attitude: "Energy drinks make me feel more relaxed”. Most agree young people (17\%), while all old persons disapprove (0\%).
Kruskal-Wallis's $H$ test showed significant differences between the age groups $(x 2=17.823, p=$ 0.003 ) for the statement that consumption of energy drinks improves concentration while driving.

A statistical significance of the difference in the statements "I do not notice the effects of energy drinks on my driving" was determined for age groups ( $x 2=15.666, p=0.008)$, where $47.8 \%$ respondents aged $36-45$ support this position, which is significantly higher than other groups. The similar results are determined in the attitude "I do not notice the effects of caffeine on my driving", between age groups ( $x 2=$ 18.797, $p=0.002$ ).

\subsection{The influence of energy drinks on driving}

Figure 2 shows a crossing of attitudes towards the statements "Energy drinks have a positive effect on my driving," and "I do not notice the effects of energy

Table 2 - Overview of statistical analyses of driver's attitudes about the impact of energy drinks and caffeine on their driving

\begin{tabular}{|c|c|c|c|c|c|}
\hline \multirow[t]{2}{*}{ Attitudes } & \multicolumn{3}{|c|}{$\begin{array}{l}\text { Mann-Withney test } \\
\text { (by gender) }\end{array}$} & \multicolumn{2}{|c|}{$\begin{array}{c}\text { Kruskal-Wallis test } \\
\text { (by education) }\end{array}$} \\
\hline & $\mathrm{U}$ & Z & $\mathrm{p}$ & $x^{2}$ & $\mathrm{p}$ \\
\hline Energy drinks make me feel more relaxed. & $4,465.5$ & -2.020 & 0.043 & 12.850 & 0.005 \\
\hline Energy drinks make me feel calmer. & $5,021.5$ & -0.676 & 0.499 & 8.657 & 0.034 \\
\hline Energy drinks make me feel more nervous. & 5,290 & -0.016 & 0.987 & 8.826 & 0.032 \\
\hline Energy drinks improve my concentration when driving. & $5,073.5$ & -0.542 & 0.588 & 7.234 & 0.065 \\
\hline I consume energy drinks because of headache. & 5,204 & -0.237 & 0.813 & 3.611 & 0.307 \\
\hline I consume energy drinks when I'm sleepy, and should drive. & 4,619 & -1.640 & 0.101 & 9.307 & 0.025 \\
\hline I consume energy drinks before a long drive. & 5,100 & -0.475 & 0.635 & 7.247 & 0.064 \\
\hline Energy drinks are a replacement for sleep. & 5,235 & -0.153 & 0.879 & 6.146 & 0.105 \\
\hline I do not notice the impact of energy drinks on my driving. & 4,435 & -2.076 & 0.038 & 9.254 & 0.026 \\
\hline Energy drinks eliminate short-term fatigue at the wheel. & $4,879.5$ & -1.006 & 0.314 & 3.423 & 0.331 \\
\hline Energy drinks have a positive effect on my driving. & 4,503 & -1.940 & 0.052 & 6.687 & 0.083 \\
\hline My reflexes are better after consuming energy drinks. & $4,780.5$ & -1.264 & 0.206 & 4.390 & 0.222 \\
\hline My concentration is better after consuming energy drinks. & $4,425.5$ & -2.109 & 0.035 & 9.099 & 0.028 \\
\hline Caffeine makes me feel more relaxed. & $4,989.5$ & -0.740 & 0.459 & 3.337 & 0.343 \\
\hline Caffeine makes me feel calmer. & $4,795.5$ & -1.219 & 0.223 & 3.472 & 0.324 \\
\hline Caffeine makes me feel more nervous. & $4,725.5$ & -1.405 & 0.160 & 1.458 & 0.692 \\
\hline Caffeine improves my concentration when driving. & 5,039 & -0.624 & 0.533 & 2.487 & 0.478 \\
\hline I consume caffeine because of headache. & $4,821.5$ & -1.145 & 0.252 & 5.876 & 0.118 \\
\hline I consume caffeine when I'm sleepy, and should drive. & $5,293.5$ & -0.007 & 0.994 & 7.545 & 0.056 \\
\hline I consume caffeine before a long drive. & $4,568.5$ & -1.751 & 0.080 & 1.912 & 0.591 \\
\hline Caffeine is a replacement for sleep. & $5,289.5$ & -0.017 & 0.986 & 1.407 & 0.704 \\
\hline I do not notice the effects of caffeine on my driving. & $4,617.5$ & -1.642 & 0.101 & 7.268 & 0.064 \\
\hline Caffeine eliminates short-term fatigue at the wheel. & $5,077.5$ & -0.529 & 0.597 & 5.891 & 0.117 \\
\hline Caffeine has a positive effect on my driving. & $5,231.5$ & -0.157 & 0.875 & 3.275 & 0.351 \\
\hline My reflexes are better after consuming caffeine. & $5,159.5$ & -0.335 & 0.737 & 1.462 & 0.691 \\
\hline I feel more rested after taking caffeine. & $5,148.5$ & -0.358 & 0.720 & 8.412 & 0.038 \\
\hline
\end{tabular}


drinks on my driving." On the x-axis the numbers from 1 to 5 represent the level of agreement of the respondents, from "I completely disagree" to "I completely agree", and on the y-axis is the percentage distribution of attitudes concerning the question: "Energy drinks have a positive effect on my driving". It was noticed that about $75 \%$ of respondents do not agree with any of the attitudes, that is, they notice that energy drinks affect their driving, but those are not positive effects. This may lead to the conclusion that if the influence is noticed, and it is not positive, then it is negative. About $1 \%$ of the respondents consider that the influence is positive. About $6 \%$ of the respondents who disagreed with the statement: "I do not notice the effects of energy drinks on my driving," believe that this influence is positive. Of those who do not notice the influence, approximately $1 \%$ agrees that energy drinks have a positive effect on their driving. This may be one of the additional indicators that the survey was conducted successfully, and that a very small number of respondents filled the survey irresponsibly.

\subsection{The influence of caffeine on driving}

Figure 3 shows the crossing of attitudes towards the statements: "Caffeine has positive effects on my driving," and "I do not notice the effects of caffeine." About 15\% of respondents believe that they noticed positive effects of caffeine. About $5 \%$ of respondents gave a contradictory attitude toward the effects of caffeine on their driving, because they stated: "I do not notice the effects of caffeine; caffeine has positive effects on my driving."
Based on the analysis of the obtained results it is concluded that attitudes are more affected by the type of the substance than by gender (Table 3).

\subsection{The influence of energy drinks vs. caffeine}

When comparing the results of the effects of energy drinks and caffeine, it can be noticed that after consuming energy drinks $6 \%$ of respondents feel calmer and $11 \%$ more nervous. After consuming caffeine $20 \%$ of respondents feel calmer and $10 \%$ more nervous. These results are drastically different than the results of the research done by [15] which shows that $78.5 \%$ of drivers feel calmer after consuming Gripin, and $3.1 \%$ more nervous. Unlike the Turkish drivers, in our research most of the drivers in Serbia do not agree with any of the three statements about the effects of energy drinks. About $50 \%$ of respondents in Serbia believe that caffeine improves concentration while driving.

We assume that the above mentioned reason is because our Study included all drivers, while Yildirim [15] included just professional drivers, who drive much more, so the impact of these drinks is stronger (e.g., $78.5 \%$ vs. $20 \%)$.

\section{DISCUSSION}

Fatigue is one of the important elements that affect the drivers and their behaviour while driving. In order to reach the destination earlier, many choose to eliminate fatigue by consuming beverages that will

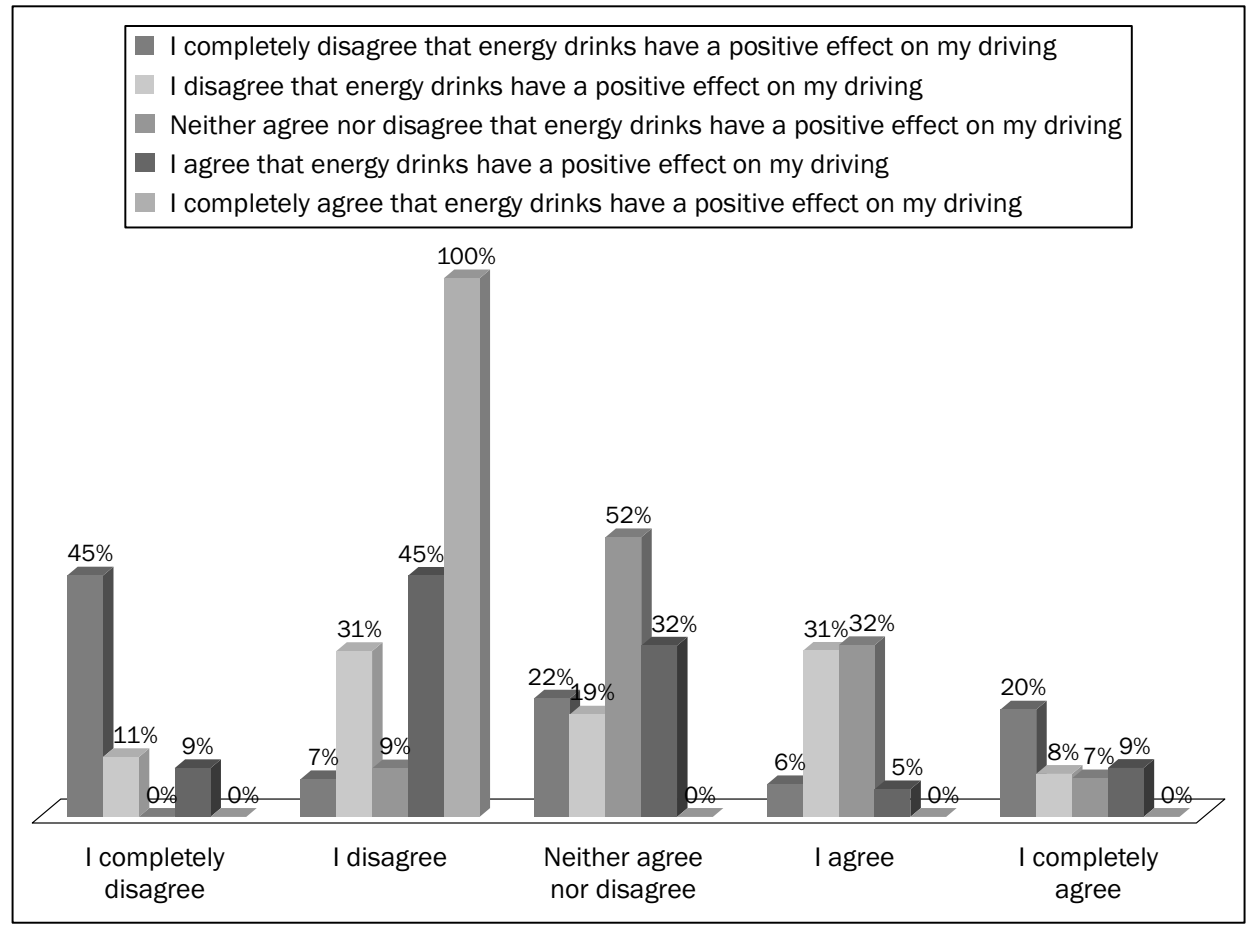

Figure 2 - The influence of energy drinks on driving 


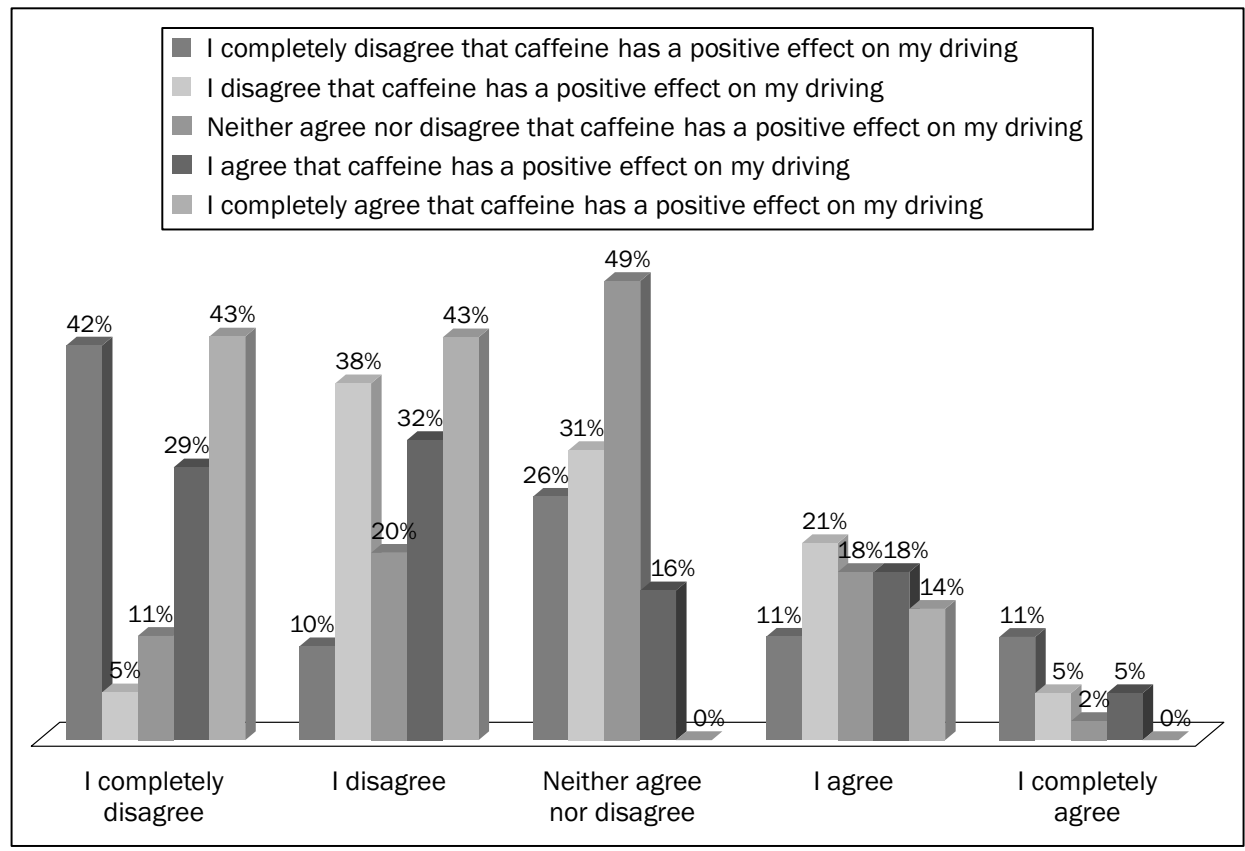

Figure 3 - The influence of caffeine on driving

Table 3 - Effect size type of substance /gender

\begin{tabular}{||l|l|c|c|c||}
\hline \hline \multirow{3}{*}{ Enpe of substance } & Feeling after consumption & $\omega_{\text {type }}^{2}$ & $\omega_{\text {gender }}^{2}$ & $\omega_{\text {type }}^{2}$ gender \\
\hline \hline \multirow{3}{*}{ Caffeine } & More rested & 0.113934 & -0.000800 & 0.028977 \\
\cline { 2 - 5 } & Calmer & 0.081764 & 0.001241 & 0.015889 \\
\cline { 2 - 5 } & More nervous & 0.019854 & -0.000630 & -0.003430 \\
\hline & More rested & 0.024632 & -0.000040 & 0.022031 \\
\cline { 2 - 5 } & Calmer & 0.017899 & 0.007565 & 0.024246 \\
\cline { 2 - 5 } & More nervous & 0.013683 & 0.000403 & 0.003853 \\
\hline
\end{tabular}

affect their central nervous system by removing fatigue and suppressing the need for sleep. They usually choose an energy drink that is sold in cans, easy to use and acting fast. Many studies indicated that the effects of energy drinks are strongest 30 minutes after consumption, and that their effect decreases during the next hour. Beside energy drinks, caffeine is also consumed, especially by older drivers. Caffeine is consumed in different ways, through fizzy drinks, chocolate, tea, but most often through coffee.

Energy drinks and caffeine, which is the main ingredient of energy drinks, in large quantities might affect the health very adversely, thus affecting traffic safety, because large amounts of energy drinks may have effects similar to those of alcohol. They affect reflexes, perception and response of drivers. In order to prevent the consequences of taking large amounts of energy drinks, particularly among young drivers, education is proposed.

According to the statements of the respondents, $8 \%$ consume energy drinks due to headaches, $14 \%$ to prevent sleep and about $4 \%$ for both reasons, whereas $24 \%$ of respondents consume caffeine due to headaches, $31 \%$ to prevent sleep and $15 \%$ for both rea- sons. The results of the research conducted in Turkey [15] indicate that as for the drivers who take Gripin, $47.7 \%$ of them take it due to headaches, $38.5 \%$ to prevent sleep and $13.8 \%$ for both reasons. Hence, it can be concluded that the results obtained in the conducted survey are similar to the research results in Turkey [15].

This survey covered all age groups, and it was found that people who are over 55 almost never consume energy drinks, whereas $60 \%$ of respondents younger than 25 consume energy drink at least a couple of times a month. All age groups consume caffeine through coffee and tea, but the respondents who are under 55 consume it more than the older ones.

We also found that respondents with higher education consume significantly more energy drinks when they are sleepy and need to drive than those with primary education (40\% vs. $2 \%$ ). However, participants with higher education least perceive the impact of energy drinks. Energy drinks are usually consumed by young drivers (18-25). Forty percent of them noticed their impact on driving. Older drivers rarely consume energy drinks, but more often consume coffee and/or tea than younger drivers. 
Unlike previous studies, this Study shows the participant's opinions and attitudes about the consumption of energy drinks and caffeine, not only by gender but also by age and education. In this way the most dangerous groups of drivers can be determined.

The main limitation of this paper is the big difference in the distributions by age, time of driving, the frequency of the consumption of coffee / energy drinks. It is the consequence of the method of data collection. This study was conducted on a random sample. Because of that, it was not possible to know in advance the certain participation of observed categories.

Numerically uneven size group can be explained as the consequence of the age structure of the study area. Specifically, Belgrade has the largest university in Serbia, and a large proportion of young people (1825 years) in the total population.

\section{CONCLUSION}

Numerous studies have been conducted in the world, and they show that caffeine has a significant influence on sleep. However, it was also found that it has a negative effect on the central nervous system, attention and concentration decrease. During the last ten years, there has been a considerable increase in the consumption of energy drinks. Energy drinks are most often consumed by young people, especially students.

Due to the resulting structure of the respondents, who were randomly generated, the findings on attitudes about the effects of energy drinks and caffeine may not be representative, but it was found that age structures representative for research on the impact of energy drinks and caffeine. This has eliminated a large part of the population; a target group does not consist of all drivers, especially drivers who consume energy drinks (18-35 years). Based on the results of the research, young drivers are categorized as a risk group, because $60 \%$ of the drivers who are under 25 consume energy drinks.

Education should be conducted among young people before they pass the driving test, in order to affect their consciousness so that they understand, before they begin to participate in traffic independently, why one needs to start driving rested, and that when they feel the signs of fatigue they should stop, take a break, and then continue their journey. If one wants the education to give results, it is necessary, beside the theory, to point out the practical examples, to show the consequences of accidents caused by fatigue and the negative effects of caffeine. On the basis of the analysis of the obtained results it is concluded that attitudes are more affected by the type of the substance than by gender

It is also necessary to give advice to future drivers what is the right way to eliminate fatigue, like a short nap up to 15 minutes or, if fatigue is to be removed in short term, to exercise for 15 minutes. It should be emphasized that it is considerably better to drink a cup of coffee than a can of energy drink. Finally, it is necessary to affect the consciousness of young people, because if they are aware of the severity of consequences in most cases they will not expose themselves to risk.

A huge problem everywhere in the world is that there is no legal limit for the intake of energy drinks in the driver's body. As a necessary measure it has been proposed to clearly define the allowed levels of energy drinks in blood, as well as to define the penalties for exceeding, as defined for the BAC level.

We should keep in mind that this is quite an unexplored area, especially on the territory of Serbia, so it has been proposed to make more detailed studies in this area, which will be based on laboratory tests modelled on foreign experiences, but also on the real situation, not only the attitudes of drivers. The aim is to determine not only the driver's attitudes but also the reality on the roads, in order to define the legal limits. In Serbia, no research about driver's attitudes to the impact of caffeine and energy drinks on road traffic safety have been conducted, so this paper investigates this research space and thus represents the basis for future research.

\section{Doc. Dr DALIBOR PEŠIĆ}

e-mail: d.pesic@sf.bg.ac.rs

Doc. Dr BORIS ANTIĆ

e-mail: b.antic@sf.bg.ac.rs

Univerzitet u Beogradu, Saobraćajni fakultet

Vojvode Stepe 305, 11000 Beograd, Srbija

Prof. Dr DAVOR BRČIĆ

e-mail: dbrcic@fpz.hr

Sveučilište u Zagrebu, Fakultet prometnih znanosti

Vukelićeva 4, 10000 Zagreb, Hrvatska

JELICA DAVIDOVIĆ, mast. inž. saobraćaja

e-mail: jelicadavidovic@yahoo.com

Univerzitet u Beogradu, Saobraćajni fakultet

Vojvode Stepe 305, 11000 Beograd, Srbija

\section{REZIME}

\section{STAVOVI VOZAČA O UTICAJU KOFEINA I ENERGETSKIH NAPITAKA NA BEZBEDNOST SAOBRAĆAJA}

Velike količine energetskih napitaka i kofeina, koji su glavni sastojak energetskih napitaka proizvode negativan uticaj na vozače $i$ bezbednost saobraćaja.

U cilju utvrđivanja stavova vozača o uticaju energetskih napitaka i kofeina, sprovedeno je anketno istraživanje gde su ciljna grupa vozači. Istraživanje je sprovedeno u Beogradu, u decembru 2012. godine. Podeljeno je 420 upitnika vozačima različite starosne kategorije od kojih je 412 vraćeno. Ankete su anonimne i sastoje se iz dva dela. Prvi deo je namenjen za prikupljanje demografskih informacija, zaokruživanjem jednog od ponuđenih odgovora i sastojao se od 8 pitanja. Drugi deo je namenjen za prikupljanje stavova o energetskim napicima i kofeinu i sastoji se od 26 pitanja. 
Ispitanici su popunjavanjem petostepenih skala pokazivali nivo slaganja sa datim stavovima.

Drugi deo je namenjen za prikupljanje stavova o energetskim napicima i kofeinu i sastoji se od 26 pitanja. Ispitanici su popunjavanjem petostepenih skala pokazivali nivo slaganja sa datim stavovima.

Rezultati pokazuju da energetske napitke najčešće konzumiraju mladi ljudi, mlađi od 25 godina. Uticaj kofeina na pol vozača je statistički značajan. Zbog glavobolje češće konzumiraju kofein (25\%) nego energetske napitke (8\%).

Veliki uticaj energetskih napitaka i kofeina na bezbednost saobraćaja ukazuje na neophodne preventivne mere poput edukacije.

\section{KLUUČNE REČl}

bezbednost saobraćaja; energetski napici; kofein; uticaj na ponašanje vozača;

\section{REFERENCES}

[1] Reyner LA, Horne JA. Early morning driver sleepiness: effectiveness of $200 \mathrm{mg}$ caffeine. Psychophysiol. 2000;37:251-256.

[2] Dragač R, Vujanić M. Road safety, Faculty of Transport and Traffic Engineering, Belgrade; 2002.

[3] Brice C, Smith A. The effects of caffeine on simulated driving, subjective alertness and sustained attention. Hum Psychopharmacol Clin Exp. 2001;16:523-531.

[4] Regina EG, Smith GM, Keiper CG, McKelvey RK. Effects of caffeine on alertness in simulated automobile driving. J Appl Psychol. 1974;59:483-489.

[5] Childs E, De Wit H. Subjective, behavioral, and physiological effects of acute caffeine in light, nondependent caffeine users. Psychopharmacol. 2006;185:514-523.

[6] Haskell CF, Kennedy DO, Wesnes KA, Scholey AB. Cog nitive and mood improvements of caffeine in habitual consumers and habitual non-consumers of caffeine. Psychopharmacol. 2005;179:813-825.

[7] Zhang M, Bi LF, Ai YD, Yang LP, Wang HB, Liu ZY, Sekine M, Kagamimori S. Effects of taurine supplementation on VDT work induced visual stress. Amino Acids. 2004;26:59-63.

[8] Shved DW, Godsey JL, Ledyard SL, Mahoney AP, Stetson $\mathrm{PL}, \mathrm{Ho}$ S, et al. Absorption, tissue distribution, metabolism and elimination of taurine given orally to rats. Amino Acids. 2007;32:459-466.

[9] Kim W. Debunking the effects of taurine in Red Bull Energy Drink. Nutr Bytes. 2003;9:1-7.

[10] Warburton DM, Bersellini E, Sweeney E. An evaluation of a caffeinated taurine drink on mood, memory and information processing in healthy volunteers without caffeine abstinence. Psychopharmacol. 2001;158:322328.

[11] Seidl R, Peyrl A, Nicham R, Hauser E. A taurine and caffeine-containing drink stimulates cognitive performance and wellbeing. Amino Acids. 2000;19:635-642.

[12] Reyner LA, Horne JA. Efficacy of a 'functional energy drink' in counteracting driver sleepiness. Physiology \& Behavior. 2002;75:331-335.

[13] Monique AJ, Ketzer S, Blom K, Maartje H, van Gerven, van Willigenburg G, Olivier B, Verster C. Positive effects of Red Bull $®$ Energy Drink on driving performance during prolonged driving. Psychopharma. 2011;214:737745.

[14] Temple GJ, Warm SJ, Dember NW, Jones SK, LaGrange MC, Matthews G. The Effects of Signal Salience and Caffeine on Performance, and Stress in an Abbreviated Vigilance Task. Human Factors: The Journal of the Human Factors and Ergonomics Society. 2000;42:183.

[15] Yildirim CR. Caffeine consumption in drivers of heavy vehicles in Turkey. Journal of the Royal Institute of Public Health. 2003;117:329-332. 